\title{
Analysis of the efficacy of HIV protease inhibitors against SARS-CoV-2's main protease
}

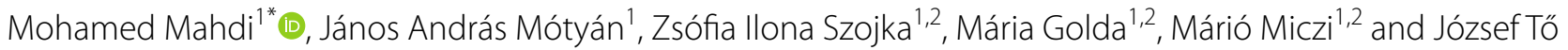 \\ zsér $^{1}$
}

\begin{abstract}
Background: The pandemic caused by severe acute respiratory syndrome coronavirus 2 (SARS-CoV-2) has resulted in millions of infections worldwide. While the search for an effective antiviral is still ongoing, experimental therapies based on repurposing of available antivirals is being attempted, of which HIV protease inhibitors (PIs) have gained considerable interest. Inhibition profiling of the Pls directly against the viral protease has never been attempted in vitro, and while few studies reported an efficacy of lopinavir and ritonavir in SARS-CoV-2 context, the mechanism of action of the drugs remains to be validated.
\end{abstract}

Methods: We carried out an in-depth analysis of the efficacy of HIV PIs against the main protease of SARS-CoV-2 $\left(\mathrm{M}^{\mathrm{pro}}\right)$ in cell culture and in vitro enzymatic assays, using a methodology that enabled us to focus solely on any potential inhibitory effects of the inhibitors against the viral protease. For cell culture experiments a dark-to-bright GFP reporter substrate system was designed.

Results: Lopinavir, ritonavir, darunavir, saquinavir, and atazanavir were able to inhibit the viral protease in cell culture, albeit in concentrations much higher than their achievable plasma levels, given their current drug formulations. While inhibition by lopinavir was attributed to its cytotoxicity, ritonavir was the most effective of the panel, with $I C_{50}$ of $13.7 \mu \mathrm{M}$. None of the inhibitors showed significant inhibition of SARS-CoV-2 $\mathrm{M}^{\text {pro }}$ in our in vitro enzymatic assays up to $100 \mu \mathrm{M}$ concentration.

Conclusion: Targeting of SARS-COV-2 M $\mathrm{M}^{\text {pro }}$ by some of the HIV PIs might be of limited clinical potential, given the high concentration of the drugs required to achieve significant inhibition. Therefore, given their weak inhibition of the viral protease, any potential beneficial effect of the PIs in COVID-19 context might perhaps be attributed to acting on other molecular target(s), rather than SARS-CoV-2 $\mathrm{M}^{\text {pro. }}$.

Keywords: SARS-CoV-2, Protease, HIV protease inhibitors, In vitro assay, Inhibition profiling

\section{Background}

In December 2019, a novel severe acute respiratory syndrome coronavirus 2 (SARS-CoV-2) was identified as the etiological agent of viral pneumonia cases that occurred in Wuhan, Hubei Province, China. As of October 29th

\footnotetext{
*Correspondence: mohamed@med.unideb.hu

${ }^{1}$ Laboratory of Retroviral Biochemistry, Department of Biochemistry and Molecular Biology, Faculty of Medicine, University of Debrecen, Egyetem tér 1. Life Science Building, Debrecen 4032, Hungary Full list of author information is available at the end of the article
}

2020, the pandemic has resulted in more than 44 million infections, and 1 million deaths worldwide according to the World Health Organization.

There is currently no standardized treatment protocol, and there is no antiviral treatment of proven efficacy recommended for COVID-19. Clinical management of patients is mainly supportive, including supplementary oxygen and mechanical ventilation if needed. However, given the overwhelming burden of the pandemic on national healthcare systems and the global economy, experimental therapies have been attempted,

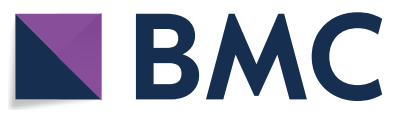

(c) The Author(s) 2020. Open Access This article is licensed under a Creative Commons Attribution 4.0 International License, which permits use, sharing, adaptation, distribution and reproduction in any medium or format, as long as you give appropriate credit to the original author(s) and the source, provide a link to the Creative Commons licence, and indicate if changes were made. The images or other third party material in this article are included in the article's Creative Commons licence, unless indicated otherwise in a credit line to the material. If material is not included in the article's Creative Commons licence and your intended use is not permitted by statutory regulation or exceeds the permitted use, you will need to obtain permission directly from the copyright holder. To view a copy of this licence, visit http://creativecommons.org/licenses/by/4.0/. The Creative Commons Public Domain Dedication waiver (http://creativeco mmons.org/publicdomain/zero/1.0/) applies to the data made available in this article, unless otherwise stated in a credit line to the data. 
which are predominantly based on the repurposing of FDA approved antivirals, antimalarials, arthritis drugs, and blood plasma derivatives [1].

The HIV protease inhibitors (PIs) lopinavir and ritonavir have gained particular interest, having shown documented in vitro activity against SARS-CoV and the Middle East respiratory syndrome coronavirus (MERS), however, these studies did not identify a molecular target for the drugs, since their efficacy was solely determined based on the inhibition of cytopathic effects or viral replication, respectively [2,3]. Given the $94.4 \%$ identity in amino acid sequence between SARS-CoV and SARS-CoV-2 [4], studying the efficacy of HIV protease inhibitors against SARS-CoV-2 would be of major relevance.

The genome of SARS-CoV-2 encodes for two viral cysteine proteases; nsp3 (papain-like protease) and nsp5 (main protease) [5]. The main protease $\left(\mathrm{M}^{\mathrm{pro}}\right)$ of SARSCoV-2; also named chymotrypsin-like protease (3CLpr), plays a crucial role in the viral life cycle, cleaving the initial polyproteins translated from the viral RNA at at least 11 of its 14 cleavage sites. $\mathrm{M}^{\text {pro }}$ of SARS-CoV-2 shares $96 \%$ sequence identity to that of SARS-CoV. The enzyme consists of three domains; two domains (I and II) which consist of antiparallel $\beta$-barrels, and an $\alpha$-helical domain (I), which is responsible for dimerization and enzymatic activity $[6,7]$. Recent structure determination confirmed the similarities between the two enzymes [8].

One potential target for the HIV PIs is the $\mathrm{M}^{\text {pro }}$. In silico screening identified nelfinavir as its potential inhibitor [9], while lopinavir and ritonavir were found to be potential inhibitors of the viral enzyme by molecular dynamics simulation [10].

It is important to note that the HIV protease is a C2-symmetric homodimeric aspartyl protease, composed of two identical subunits that are 99 amino acids each. The active site is located at the interface between the two monomers, and contains the catalytic Asp-ThrGly residues [11]. $\mathrm{M}^{\text {pro }}$ on the other hand, is a cysteine protease that can also potentially be targeted by peptide mimetics. Given the structural difference between the two proteases, the efficacy of HIV protease inhibitors against SARS-CoV and SARS-CoV-2 is questionable.

Previous studies reported that a combination of lopinavir/ritonavir and ribavirin was effective against SARSassociated coronavirus, with concentrations of $4 \mu \mathrm{g} /$ $\mathrm{ml}$ and $50 \mu \mathrm{g} / \mathrm{ml}$, respectively [12]. However, a recent clinical trial of 99 patients with laboratory-confirmed SARS-CoV-2 infection who were treated with lopinavir-ritonavir concluded that no significant benefit was observed in the treated group, compared to those who received standard care [13]. Recently, a short communication reported that lopinavir inhibited SARS-CoV-2 replication in Vero E6 cells with $\mathrm{IC}_{50}$ of $26.63 \mu \mathrm{M}$, ritonavir, however, showed no inhibition of viral replication [14].

Early in vitro reports from China showed that darunavir inhibited SARS-CoV-2 replication, although at a very high concentration $(300 \mu \mathrm{M})$ [15]. Clinical trials are currently ongoing [16].

Our aim was to test the efficacy of a panel of HIV PIs against SARS-CoV-2 $\mathrm{M}^{\text {pro }}$, using a cell culture-based model. In this study, we determined the $\mathrm{IC}_{50}$ of the PIs with the aid of a dark-to-bright GFP substrate system that had been developed and applied previously for the investigation of caspases [17]. Moreover, in vitro enzymatic inhibitory assays were also carried out using purified $\mathrm{M}^{\text {pro }}$ and an oligopeptide substrate representing the AVLQ*SGFR cleavage site of SARS-CoV-2 polyprotein 1 ab (PP1ab).

\section{Materials and methods}

\section{Plasmids and inhibitors}

Coding sequence of SARS-CoV-2 $\mathrm{M}^{\text {pro }}$ (GenBank: MT291835.2) was cloned into pcDNA3.1 $(+)$ mammalian expression plasmid using BamHI/EcoRI restriction sites to create the SARS-CoV-2 $\mathrm{M}^{\text {pro }}$ coding plasmid; thereafter referred to as $\mathrm{CoV}-2 \mathrm{M}^{\mathrm{pro}}$. The coding sequence of a dark-to-bright GFP reporter substrate; thereafter referred to as PR-Sub, was also cloned into pcDNA3.1 $(+)$ plasmid. The PR-Sub was designed to contain a sequence representing the $\mathrm{N}$-terminal autoproteolytic cleavage site of SARS-CoV-2 M ${ }^{\text {pro }}$ (TSAVLQ*SGFRKM); corresponding to the nsp $4 / n s p 5$ cleavage site, between the GFP and the Influenza A/M2 protein hydrophobic tail (CNDSSDPLVVAASIIGILHLILWILDRL). For in vitro expression of the protease, the coding sequence of $\mathrm{His}_{6}$-tagged $\mathrm{M}^{\text {pro }}$ was cloned into pET11a bacterial expression plasmid using NdeI and BamHI enzymes. The above mentioned expression constructs were obtained using the gene synthesis service of GenScript.

The protease inhibitors darunavir, saquinavir, lopinavir, tipranavir, indinavir sulfate, and atazanavir sulfate were obtained through the NIH AIDS Reagent Program, Division of AIDS, NIAID, NIH. Ritonavir was obtained from Abbott laboratories, nelfinavir from Agouron, and atazanavir from Bristol-Myers Squibb.

A synthetic oligopeptide used in our in vitro enzymatic assay representing the $\mathrm{N}$-terminal autoproteolytic cleavage site of SARS-CoV-2 $\mathrm{M}^{\text {pro }}$ (AVLQ*SGFR) was obtained from a peptide synthesis service (BioBasic).

\section{Analysis of transfection efficiency and proteolysis}

293 T human embryonic kidney cells (HEK-293 T) (Invitrogen) were maintained in T-75 flask in $15 \mathrm{~mL}$ Dulbecco's modified Eagle's medium (DMEM) (Sigma-Aldrich) 
supplemented with $10 \%$ fetal bovine serum (FBS), 1\% glutamine and $1 \%$ penicillin-streptomycin. Cells were transfected at $70 \%$ confluency with $5 \mu \mathrm{g}$ of either PRSub, or CoV-2 $\mathrm{M}^{\text {pro }}$ plus PR-Sub plasmids using PEI method [18]. After $24 \mathrm{~h}$ incubation, GFP fluorescence was analyzed by flow cytometry using FACS Calibur (BD Biosciences).

\section{Inhibition profiling in cell culture}

On the day of transfection, HEK-293 T cells were split and transferred into a 48-well plates $(30,000$ cells/well) containing serial dilutions of the inhibitor ranging from $200 \mu \mathrm{M}$ to $5 \mathrm{nM}$ in a total volume of $200 \mu \mathrm{L}$ DMEM/ well, supplemented with $10 \%$ FBS, $1 \%$ glutamine and $1 \%$ penicillin-streptomycin. After $3 \mathrm{~h}$ incubation at $37^{\circ} \mathrm{C}$, cells were transfected with $300 \mathrm{ng}$ of CoV-2 $\mathrm{M}^{\mathrm{pro}}$ and PRSub plasmids using lipofectamine LTX reagent (Thermo Fisher Scientific), then the cells were incubated for $24 \mathrm{~h}$. GFP fluorescence was then measured by flow cytometry using FACS Calibur. The results were analyzed by FlowJo Software Version 10 (Becton, Dickinson and Company; 2019). Calculations of $\mathrm{IC}_{50}$ were performed using GraphPad Prism 5.0 (GraphPad Software, Inc).

\section{Cell viability assay}

The day before the assay, HEK-293 T cells were split into a 96-well plates (20,000 cells/well) containing serial dilutions of the inhibitor ranging from $200 \mu \mathrm{M}$ to $100 \mathrm{nM}$ in a total volume of $200 \mu \mathrm{L}$ DMEM/well, supplemented with $10 \%$ FBS, $1 \%$ glutamine and $1 \%$ penicillin-streptomycin. The next day, the medium was replaced with $100 \mu \mathrm{L}$ of OPTI-MEM culture media supplemented with $10 \%$ FBS, and $10 \mu \mathrm{L}$ of the $12 \mathrm{mM} \mathrm{3-(4,5-dimethylthiazol-2-yl)-}$ 2,5-diphenyltetrazolium bromide (MTT) stock solution was added to the cells. After $4 \mathrm{~h}$ incubation at $37^{\circ} \mathrm{C}, 85$ $\mu \mathrm{L}$ of supernatant was removed, and $50 \mu \mathrm{L}$ of DMSO was added to the cells followed by incubation for $10 \mathrm{~min}$ at $37{ }^{\circ} \mathrm{C}$. Absorbance was measured at $540 \mathrm{~nm}$ using Synergy H1 Hybrid Multi-Mode Reader (Agilent).

\section{Expression and purification of SARS-CoV-2 $\mathrm{M}^{\text {pro }}$}

The heat-shock transformed BL21(DE3) cells containing the pET11a-His ${ }_{6}-\mathrm{M}^{\text {pro }}$ plasmid were incubated in $30 \mathrm{ml}$ Luria-Bertani (LB) medium supplemented with ampicillin $\left(100 \mu \mathrm{g} / \mathrm{ml}\right.$ final concentration) at $37{ }^{\circ} \mathrm{C}$ for $16 \mathrm{~h}$. The pre-cultured medium was inoculated into $470 \mathrm{ml} \mathrm{LB}$ $\left(100 \mu \mathrm{g} / \mathrm{ml}\right.$ ampicillin) and further incubated at $37{ }^{\circ} \mathrm{C}$. Protein expression was induced by isopropyl $\beta$-D-1thiogalactopyranoside (IPTG) (1 mM final concentration) when the $\mathrm{OD}_{600}$ reached 0.6-0.8. After $3 \mathrm{~h}$ incubation, cells were pelleted by centrifugation at $4{ }^{\circ} \mathrm{C}$ for $20 \mathrm{~min}$ at $5,000 \times \mathrm{g}$ (Sorvall Lynx 4000, Thermo Fisher Scientific), the cell pellet was resuspended in $10 \mathrm{ml}$ buffer A $(20 \mathrm{mM}$
Tris, $150 \mathrm{mM} \mathrm{NaCl}, 10 \mathrm{mM}$ imidazole, $\mathrm{pH}$ 7.5) and lysed by sonication on ice (Branson Sonifier 450). After a repeated centrifugation at $4{ }^{\circ} \mathrm{C}$ for $20 \mathrm{~min}$ at $10,000 \times \mathrm{g}$, the pellet was discarded and $\mathrm{His}_{6}-\mathrm{M}^{\text {pro }}$ was purified from the supernatant by $\mathrm{Ni}$-chelate affinity chromatography with the aid of His-Trap Column (GE Healthcare) using Äkta Prime instrument (Amersham Pharmacia Biotech). The column was equilibrated and washed with buffer $\mathrm{A}$, the $\mathrm{His}_{6}-\mathrm{M}^{\mathrm{pro}}$ protein was eluted under 20 column volume with a linear gradient of imidazole $(0-500 \mathrm{mM}$ imidazole) using buffer B (20 mM Tris, $150 \mathrm{mM} \mathrm{NaCl}$, $500 \mathrm{mM}$ imidazole, $\mathrm{pH}$ 7.5). Afterwards, the purification buffer was exchanged to buffer C ( $20 \mathrm{mM}$ Tris, $50 \mathrm{mM}$ $\mathrm{NaCl}, 2 \mathrm{mM} \mathrm{CaCl}$ pH 7.5) using Amicon Ultra centrifugal filters (10 K, Merck Millipore) and then the protein was incubated with Factor Xa $(10 \mu \mathrm{g} F \mathrm{Fa} / \mathrm{mg}$ protein, BCXA-1060, Haematologic Technologies) at $16{ }^{\circ} \mathrm{C}$ for $16 \mathrm{~h}$ to remove $\mathrm{His}_{6}$ fusion tag. Before the next purification step, the buffer was changed to buffer D $(20 \mathrm{mM}$ Tris, $1 \mathrm{mM}$ DTT, $\mathrm{pH}$ 8.0) and the protein was further purified by ion-exchange chromatography using HiTrap Q FF column (GE Healthcare) equilibrated with buffer D, and eluted with buffer $\mathrm{E}(20 \mathrm{mM}$ Tris, $1 \mathrm{M} \mathrm{NaCl}, 1 \mathrm{mM}$ DTT, pH 8.0) under 20 column volume with a linear gradient. The high-purity fractions of the untagged $\mathrm{M}^{\text {pro }}$ were dialyzed against buffer F (20 mM HEPES, $120 \mathrm{mM}$ $\mathrm{NaCl}, 0.4 \mathrm{mM}$ EDTA, $4 \mathrm{mM}$ DTT, 20\% glycerol pH 6.5), and stored at $-20^{\circ} \mathrm{C}$ in a small-volume aliquots.

\section{In vitro protease assay}

The AVLQ*SGFR oligopeptide was dissolved in distilled water and was used as substrate in activity measurements to test the inhibitory potential of the PIs.

The cleavage reactions contained $10 \mu \mathrm{L}$ reaction buffer (20 mM Tris, $100 \mathrm{mM} \mathrm{NaCl}, \mathrm{pH} 7.8$ ), $4.8 \mu \mathrm{L}$ oligopeptide substrate (1.37 mM final concentration), and $0.2 \mu \mathrm{L}$ DMSO (in control samples) or $0.2 \mu \mathrm{L}$ of the inhibitor (diluted in DMSO). For inhibitor screening, inhibitors were applied in $100 \mu \mathrm{M}$ final concentration. Reactions were initiated by the addition of $5 \mu \mathrm{L}$ of $\mathrm{M}^{\text {pro }}$ in a final total protein concentration of $0.12 \mu \mathrm{M}$, and the mixtures were incubated at $37^{\circ} \mathrm{C}$ for $10 \mathrm{~min}$. The reactions were terminated by the addition of $180 \mu \mathrm{L} 1 \%$ trifluoroacetic acid (TFA). The cleavage products were detected using high performance liquid chromatography (HPLC), utilizing a $0-100 \%$ water-acetonitrile gradient in the presence of TFA using Merck Hitachi instrument. Relative activity was determined at less than $20 \%$ substrate hydrolysis. Activity measured in the presence of DMSO was considered to be $100 \%$. While no potent inhibitor of $\mathrm{M}^{\text {pro }}$ was available to perform active-site titration, $100 \%$ activity was assumed for the enzyme. 


\section{Modeling}

Homology modeling of dark-to-bright GFP substrate was performed using Phyre2 web portal [19]. 97\% of residues were modelled at $>90 \%$ confidence. Structural figures were prepared PyMol Molecular Graphics System (Version 1.3 Schrödinger, LLC).

\section{Results}

\section{Inhibition profiling in cell culture}

To measure $\mathrm{M}^{\text {pro }}$ activity in cell culture experiments, we applied a modified version of a dark-to-bright GFP reporter substrate [17] which was adapted in this study for SARS-CoV-2 $\mathrm{M}^{\text {pro }}$. The recombinant substrate consists of an N-terminal GFP, followed by a natural proteolytic cleavage site of SARS-CoV-2 polyprotein, and a $\mathrm{C}$-terminal hydrophobic tail. Proteolysis at the inserted cleavage site releases the tail that serves as a hydrophobic quencher of fluorescence and facilitates tetramerization of GFP, which prevents chromophore maturation; the fluorescence is restored upon proteolysis (Fig. 1).
Firstly, we optimized the transfection of HEK-293 T cells for the use of the SARS-CoV-2 $\mathrm{M}^{\text {pro }}$ and the darkto-bright GFP substrate. Transfection of cells with only the PR-Sub plasmid resulted in a maximum of $1 \%$ background fluorescence after $24 \mathrm{~h}$ incubation. When cells were transfected with both the PR-Sub and $\mathrm{CoV}-2 \mathrm{M}^{\text {pro }}$ plasmids, GFP fluorescence ranged from $28-34 \%$, indicating processing of the substrate and the activity of the protease (Fig. 2).

We then analyzed the inhibition efficacy of a panel of HIV PIs against SARS-CoV-2 $\mathrm{M}^{\text {pro }}$. While none of the inhibitors was able inhibit the viral protease in nanomolar concentration; which is expected for effective transition state analogs, in micromolar range, ritonavir was the most effective $\left(\mathrm{IC}_{50}=13.7 \pm 1.1 \mu \mathrm{M}\right)$. Saquinavir, darunavir, and atazanavir were also able to inhibit SARS-CoV-2 $\mathrm{M}^{\text {pro }}$ at higher concentrations (Table 1).

Although a combination of lopinavir and ritonavir resulted in better inhibition of the viral enzyme as compared to ritonavir alone $(10.9 \mu \mathrm{M}$ vs. $13.7 \mu \mathrm{M}$, respectively), when we carried out cell viability assays

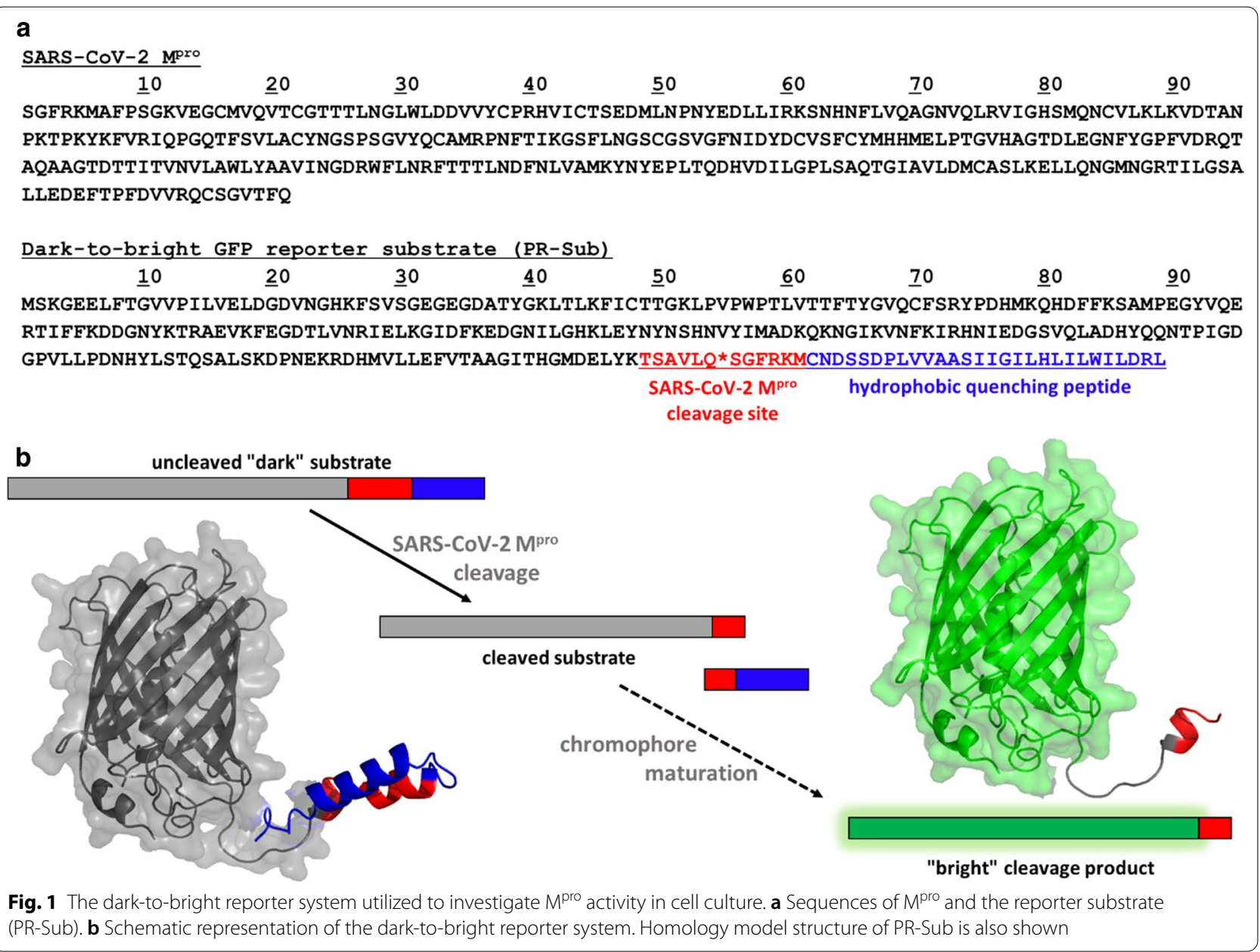



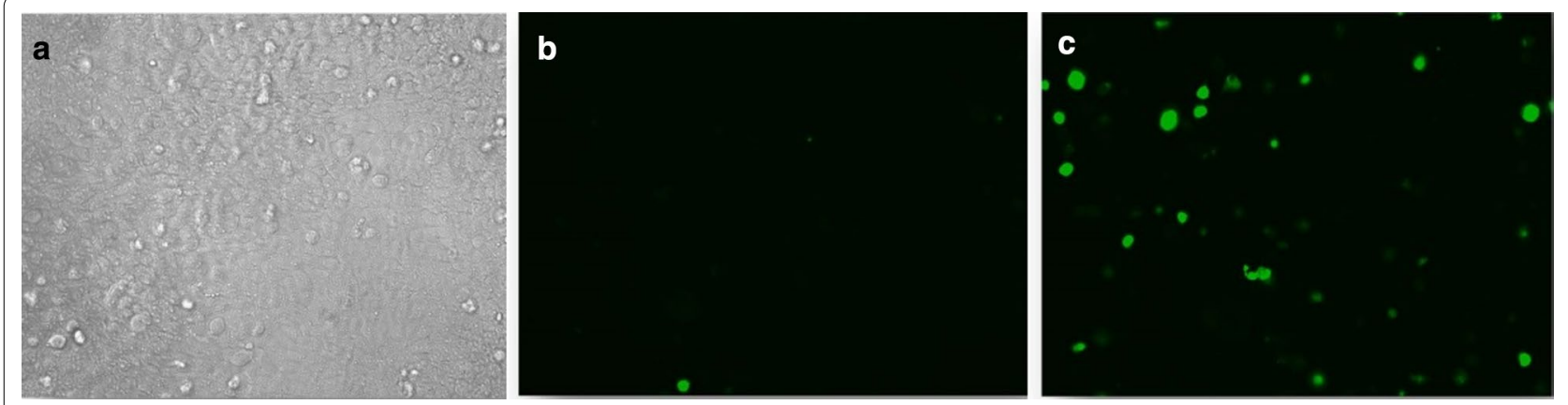

Fig. 2 Optimization of HEK-293 T cell transfection with SARS-CoV-2-Mpro and the dark-to-bright GFP substrate. a Cells transfected with PR-Sub and CoV-2 $\mathrm{M}^{\text {pro }}$ under native microscopic light. $\mathbf{b}$ Visualization of cells transfected with PR-Sub under fluorescent microscope. $\mathbf{c}$ Visualization of cells transfected with PR-Sub and CoV-2 M pro under fluorescent microscope. Co-transfection with both plasmids resulted in 28-34\% GFP fluorescence

Table 1 Results of inhibition profiling of HIV protease inhibitors against SARS-CoV-2 $\mathrm{M}^{\text {pro }}$ in cell culture. Data are calculated from triplicate experiments. ${ } \mathrm{C}_{50}$ for lopinavir was indeterminable accurately due to high cytotoxic effects in HEK-293 T cells

\begin{tabular}{lll}
\hline Inhibitor & $\mathbf{I C}_{\mathbf{5 0}}(\boldsymbol{\mu M})$ & Standard error \\
\hline Lopinavir + Ritonavir & 10.9 & \pm 1.1 \\
Ritonavir & 13.7 & \pm 1.1 \\
Saquinavir & 31.4 & \pm 1.2 \\
Darunavir & 36.1 & \pm 1.2 \\
Atazanavir & 60.7 & \pm 2.5 \\
Lopinavir & Indeterminable & \\
Indinavir & No inhibition (up to $200 \mu \mathrm{M})$ & \\
Nelfinavir & No inhibition (up to $200 \mu \mathrm{M})$ & \\
Tipranavir & No inhibition (up to $200 \mu \mathrm{M})$ & \\
\hline
\end{tabular}

after treatment of the cells with the inhibitors, interestingly, inhibition by lopinavir was found to be a result of the high cytotoxicity observed at concentrations above $50 \mu \mathrm{M}$ (90\%) (Fig. 3).

In the case of ritonavir and saquinavir, cytotoxicity of $>50 \%$ was only observed at concentrations above $50 \mu \mathrm{M}$. High concentrations of darunavir and atazanavir on the other hand, were well tolerated by HEK-293 T cells.

Indinavir, nelfinavir and tipranavir however, failed to inhibit SARS-CoV-2 M $\mathrm{M}^{\text {pro }}$, even at 200 micromolar concentration of the inhibitors.

\section{In vitro enzymatic assay}

Following expression and purification of the untagged $M^{\text {pro }}$, we determined its catalytic activity after incubation with the AVLQ*SGFR oligopeptide substrate. Cleavage position within the substrate was determined using high-performance liquid chromatography coupled to electrospray ionization time-of-flight mass spectrometry
(HPLC-ESI-TOF MS) (Additional file 1: Fig. 1). Inhibition profiling of the PIs was carried out after incubation of the inhibitors along with $\mathrm{M}^{\mathrm{pro}}$ and the substrate, and the relative efficacies of PIs were compared. None of the inhibitors showed a significant inhibition of the $\mathrm{M}^{\text {pro }}$ in vitro ( $p$ values $>0.05$ ) (Fig. 4).

\section{Discussion}

To our knowledge, direct determination of the inhibition efficacy of HIV PIs against SARS-CoV-2 $\mathrm{M}^{\text {pro }}$ in cell culture has not yet been published, although many in silico studies analyzing interaction between SARS-CoV-2 $\mathrm{M}^{\text {pro }}$ and potential inhibitors were published [20-26] (Additional file 1: Table 1). Antiviral assays using lopinavir and ritonavir in Calu-3 cells were previously carried out for MERS-CoV, and the $\mathrm{IC}_{50}$ for lopinavir, ritonavir and their combination was $11.6,24.9$, and $8.5 \mu \mathrm{M}$ respectively [3]. In our analysis, we found that a combination of lopinavir plus ritonavir achieved the lowest $\mathrm{IC}_{50}$, this however was due to the high cytotoxicity of lopinavir, and not as a result of direct inhibition of SARS-CoV-2 $\mathrm{M}^{\text {pro }}$. Ritonavir on the other hand was much more tolerable than lopinavir, and achieved the lowest $\mathrm{IC}_{50}$. This should be taken into consideration, given the current drug formulation of lopinavir which is in combination with ritonavir, where ritonavir is used as a pharmacokinetic enhancer due to its inhibition of the cytochrome P450 3A4 isoenzyme, thereby increasing the bioavailability of lopinavir [27]. As a result, administration of ritonavir in combination with other PIs was found to decrease its minimum blood plasma concentration level, as compared to the generic formulation of the drug [28]. Also, while our result regarding ritonavir was in direct contrast to what Choy et al. reported in their short communication [14], we believe that difference in methodologies is to blame for this discrepancy, as we examined the efficacy of ritonavir against the viral $M^{\text {pro }}$ protease per se. 

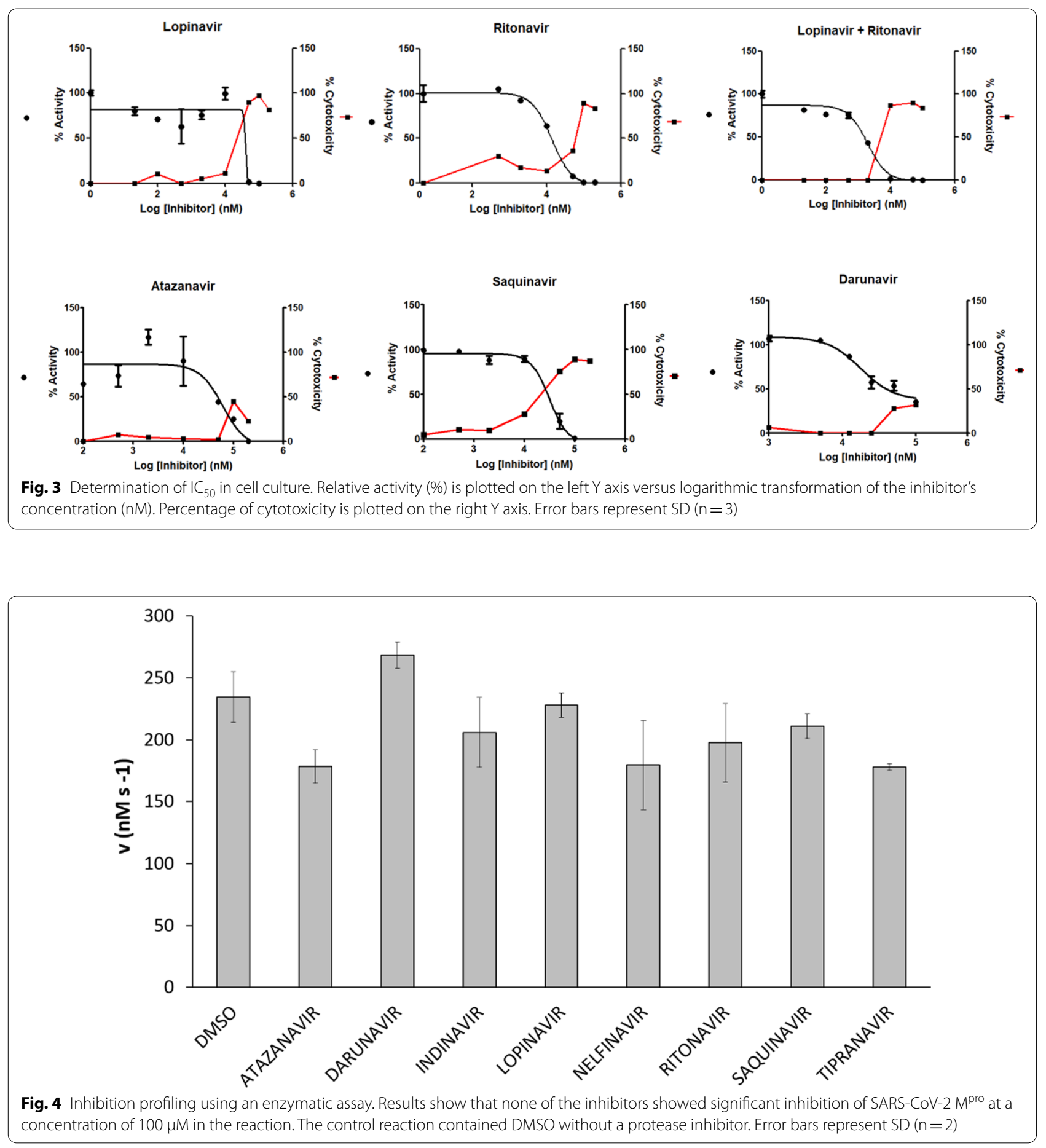

It is important to note that the $\mathrm{IC}_{50}$ of the inhibitors were in the micromolar range which is not considered optimal for the inhibition of the viral enzyme. Previous studies have reported that the minimum concentrations $\left(C_{\text {min }}\right)$ for lopinavir, darunavir, saquinavir, and atazanavir in patient's serum under antiretroviral treatment was found to be $9.3,3.3,3.8$, and $<1 \mu \mathrm{M}$, respectively [29-32]. It would indeed be challenging to achieve such high plasma levels of the inhibitors in order to block the viral replication, moreover, the cytotoxic effects of some of the inhibitors, in addition to the 
side effects commonly observed with PIs questions the use of anti-HIV PIs in the context of SARS-CoV-2.

Additionally, using an in vitro enzymatic assay, we were able to directly analyze any potential inhibition of $\mathrm{M}^{\text {pro }}$ by the HIV PIs. Our results show that none of the inhibitors was able to significantly inhibit $\mathrm{M}^{\text {pro }}$ in vitro.

A drawback of this study is that we were not able to assess the interaction between the PIs and the papainlike protease of SARS-CoV-2, as our methodology only enabled us to study the viral main protease. Whether or not these exert any inhibitory effect on the papainlike protease is a subject for future studies, although, a similar methodology may be adapted for SARS-CoV-2 papain-like protease, and other proteases as well. Also, while our cell culture assays were not performed in SARS-CoV-2 target cells, our methodology enabled us to directly examine any potential inhibition of the viral $\mathrm{M}^{\text {pro }}$ by the PIs, therefore, it is unlikely that different results will be obtained in target cells.

\section{Conclusion}

In conclusion, to our knowledge, thorough analysis of the efficacies of PIs against SARS-CoV-2 remains scarce, and the targets of the drugs are yet to be verified. While few studies examined the efficacy of some PIs against the replication of SARS-CoV-2, we set out to study whether or not the inhibitors exert a direct effect on the viral protease. In our experiments, even though some of the PIs developed for the treatment of HIV were able to inhibit SARS-CoV-2 $\mathrm{M}^{\text {pro }}$, they were only able to do so at high concentrations. The combination of lopinavir plus ritonavir resulted in the lowest $\mathrm{IC}_{50}$ in cell culture, albeit at the cost of cellular viability. Although, darunavir and atazanavir required a much higher concentration to achieve the inhibition, cytotoxicity was not observed even at a concentration of $200 \mu \mathrm{M}$. It should be noted that there might be other molecular targets for the HIV PIs, as nelfinavir was recently shown to inhibit spike protein-mediated fusion of SARS-CoV-2 [33].

Taking everything into consideration, the use of HIV PIs in the context of COVID-19 might be of limited clinical potential, beneficial effects of which might perhaps be attributed to acting on other molecular target(s), rather than $\mathrm{M}^{\text {pro }}$ itself. Data from clinical trials will indeed shed more light on their clinical efficacy.

\section{Supplementary information}

Supplementary information accompanies this paper at https://doi. org/10.1186/s12985-020-01457-0.

Additional file 1. Supplementary figure and table.

\section{Abbreviations}

SARS-CoV-2: Severe acute respiratory syndrome coronavirus 2; HIV: Human immunodeficiency virus; PI: Protease inhibitor; $\mathrm{M}^{\text {pro: }}$ Main protease; $\mathrm{IC}_{50}$ : Half maximal inhibitory concentration; COVID-19: Coronavirus disease-2019; WHO: World Health Organization; FDA: Food and Drug Administration; MERS: Middle East respiratory syndrome; PR: Protease; PEl: Polyethylenimine; GFP: Green fluorescent protein; FACS: Fluorescence-activated cell sorting; HEK293 T: Human embryonic kidney 293 cells; DMSO: Dimethyl sulfoxide; MTT: 3-(4,5-Dimethylthiazol-2-yl)-2,5-diphenyltetrazolium bromide; IPTG: Isopropyl ß-D-1-thiogalactopyranoside; TFA: Trifluoroacetic acid; HPLC-ESI-TOF MS: High-performance liquid chromatography coupled to electrospray ionization time-of-flight mass spectrometry.

\section{Acknowledgements}

The authors would like to thank Szilvia Janics-Petó for her continuous help and technical assistance, and are grateful to the staff of the Laboratory of Retroviral Biochemistry. Authors are grateful to Tibor Nagy (Department of Applied Chemistry, Faculty of Science and Technology, University of Debrecen) for performing HPLC-ESI-TOF MS analysis.

\section{Authors' contributions}

M. Mahdi, J.A.M., and J.T. designed the experiments and interpreted the results; M. Mahdi, and Zs. Sz. carried out cell culture experiments, J.A.M., M.G., and M.

Miczi carried out in vitro experiments. All authors contributed to the writing of the manuscript, and approved the final draft.

\section{Funding}

This work was supported in part by the Higher Education Institutional Excellence Programme (NKFIH-1150-6/2019) of the Ministry of Innovation and Technology in Hungary, within the framework of the Biotechnology thematic programme of the University of Debrecen, and in part, by the Hungarian Scientific Research Fund (NKFI 125,238) to J.T. The funders had no role in the design of the study; in the collection, analyses, or interpretation of data; in the writing of the manuscript, or in the decision to publish the results.

\section{Availability of data and materials}

All data generated during this study are included in this article and its supplementary information files.

\section{Ethics approval and consent to participate}

Not applicable.

\section{Consent for publication}

Not applicable.

\section{Competing interests}

The authors declare no competing interests.

\section{Author details}

${ }^{1}$ Laboratory of Retroviral Biochemistry, Department of Biochemistry and Molecular Biology, Faculty of Medicine, University of Debrecen, Egyetem tér 1. Life Science Building, Debrecen 4032, Hungary. ${ }^{2}$ Doctoral School of Molecular Cell and Immune Biology, University of Debrecen, Debrecen, Hungary.

Received: 8 July 2020 Accepted: 20 November 2020

Published online: 26 November 2020

\section{References}

1. Li G, De Clercq E. Therapeutic options for the 2019 novel coronavirus (2019-nCoV). Nat Rev Drug Discovery. 2020;19(3):149-50. https://doi. org/10.1038/d41573-020-00016-0.

2. Chen $\mathrm{F}$, Chan KH, Jiang Y, et al. In vitro susceptibility of 10 clinical isolates of SARS coronavirus to selected antiviral compounds. J Clin Virol. 2004;31(1):69-75. https://doi.org/10.1016/j.jcv.2004.03.003.

3. Sheahan TP, Sims AC, Leist SR, et al. Comparative therapeutic efficacy of remdesivir and combination lopinavir, ritonavir, and interferon beta 
against MERS-CoV. Nat Commun. 2020;11(1):222. https://doi.org/10.1038/ s41467-019-13940-6.

4. Zhou P, Yang XL, Wang XG, et al. A pneumonia outbreak associated with a new coronavirus of probable bat origin. Nature. 2020;579(7798):270-3. https://doi.org/10.1038/s41586-020-2012-7.

5. Chan JF, Kok KH, Zhu Z, et al. Genomic characterization of the 2019 novel human-pathogenic coronavirus isolated from a patient with atypical pneumonia after visiting Wuhan. Emerg Microb Infect. 2020;9(1):221-36. https://doi.org/10.1080/22221751.2020.1719902.

6. Anand K, Ziebuhr J, Wadhwani P, et al. Coronavirus main proteinase (3CLpro) structure: basis for design of anti-SARS drugs. Science. 2003;300(5626):1763-7. https://doi.org/10.1126/science.1085658.

7. Gentile D, Patamia V, Scala A, et al. Putative inhibitors of SARS-CoV-2 main protease from a library of marine natural products: a virtual screening and molecular modeling study. Marine Drugs. 2020. https://doi. org/10.3390/md18040225.

8. Dai W, Zhang B, Su H, et al. Structure-based design of antiviral drug candidates targeting the SARS-CoV-2 main protease. Science. 2020. https://doi. org/10.1126/science.abb4489.

9. Mittal L, Kumari A, Srivastava M, et al. Identification of potential molecules against COVID-19 main protease through structure-guided virtual screening approach. J Biomol Struct Dyn. 2020. https://doi.org/10.1080/07391 102.2020.1768151.

10. Nutho B, Mahalapbutr $P$, Hengphasatporn $K$, et al. Why are lopinavir and ritonavir effective against the newly emerged coronavirus 2019? atomistic insights into the inhibitory mechanisms. Biochemistry. 2020;59(18):1769-79. https://doi.org/10.1021/acs.biochem.0c00160

11. Wlodawer A, Miller M, Jaskolski M, et al. Conserved folding in retroviral proteases: crystal structure of a synthetic HIV-1 protease. Science. 1989;245(4918):616-21. https://doi.org/10.1126/science.2548279.

12. Chu CM, Cheng VC, Hung IF, et al. Role of lopinavir/ritonavir in the treatment of SARS: initial virological and clinical findings. Thorax. 2004:59(3):252-6. https://doi.org/10.1136/thorax.2003.012658.

13. Cao $B$, Wang $Y$, Wen $D$, et al. A trial of lopinavir-ritonavir in adults hospitalized with severe Covid-19. N Engl J Med. 2020. https://doi.org/10.1056/ NEJMoa2001282.

14. Choy KT, Wong AY, Kaewpreedee P, et al. Remdesivir, lopinavir, emetine, and homoharringtonine inhibit SARS-CoV-2 replication in vitro. Antiviral Res. 2020;178:104786. https://doi.org/10.1016/j.antiviral.2020.104786.

15. Dong L, Hu S, Gao J. Discovering drugs to treat coronavirus disease 2019 (COVID-19). Drug Discov Therapeut. 2020;14(1):58-60. https://doi. org/10.5582/ddt.2020.01012.

16. Lythgoe MP, Middleton P. Ongoing clinical trials for the management of the COVID-19 pandemic. Trends Pharmacol Sci. 2020. https://doi. org/10.1016/j.tips.2020.03.006

17. Nicholls SB, Chu J, Abbruzzese G, et al. Mechanism of a genetically encoded dark-to-bright reporter for caspase activity. J Biol Chem. 2011;286(28):24977-86. https://doi.org/10.1074/jbc.M111.221648.

18. Baker A, Saltik M, Lehrmann H, et al. Polyethylenimine (PEI) is a simple, inexpensive and effective reagent for condensing and linking plasmid DNA to adenovirus for gene delivery. Gene Ther. 1997;4(8):773-82. https ://doi.org/10.1038/sj.gt.3300471.

19. Kelley LA, Mezulis S, Yates CM, et al. The Phyre2 web portal for protein modeling, prediction and analysis. Nat Protoc. 2015;10(6):845-58. https:// doi.org/10.1038/nprot.2015.053.

20. Shah B, Modi P, Sagar SR. In silico studies on therapeutic agents for COVID-19: drug repurposing approach. Life Sci. 2020;252:117652. https:// doi.org/10.1016/j.lfs.2020.117652.
21. Sang $\mathrm{P}$, Tian S-H, Meng Z-H, et al. Anti-HIV drug repurposing against SARS-CoV-2. RSC Adv. 2020;10(27):15775-83. https://doi.org/10.1039/ DORA01899F.

22. Pant S, Singh M, Ravichandiran V, et al. Peptide-like and small-molecule inhibitors against Covid-19. J Biomol Struct Dyn. 2020. https://doi. org/10.1080/07391102.2020.1757510.

23. Ortega JT, Serrano ML, Pujol FH, et al. Unrevealing sequence and structural features of novel coronavirus using in silico approaches: The main protease as molecular target. EXCLI J. 2020;19:400-9. https://doi. org/10.17179/excli2020-1189.

24. Calligari PB, Bobone S, Ricci G, Bocedi A. Molecular investigation of SARS-CoV-2 proteins and their interactions with antiviral drugs. Viruses. 2020;12:445. https://doi.org/10.3390/v12040445.

25. Beck BR, Shin B, Choi Y, et al. Predicting commercially available antiviral drugs that may act on the novel coronavirus (SARS-CoV-2) through a drug-target interaction deep learning model. Comput Struct Biotechnol J. 2020;18:784-90. https://doi.org/10.1016/j.csbj.2020.03.025.

26. Fischer A, Sellner M, Neranjan S, et al. Potential inhibitors for novel coronavirus protease identified by virtual screening of 606 million compounds. Int J Mol Sci. 2020. https://doi.org/10.3390/ijms21103626.

27. Hull MW, Montaner JS. Ritonavir-boosted protease inhibitors in HIV therapy. Ann Med. 2011;43(5):375-88. https://doi.org/10.3109/07853 890.2011 .572905

28. van der Lugt J, Lange J, Avihingsanon A, et al. Plasma concentrations of generic lopinavir/ritonavir in HIV type-1-infected individuals. Antiviral Therapy. 2009;14(7):1001-4. https://doi.org/10.3851/IMP1410.

29. Lopez-Cortes LF, Ruiz-Valderas R, Sanchez-Rivas E, et al. Lopinavir plasma concentrations and virological outcome with lopinavir-ritonavir monotherapy in HIV-1-infected patients. Antimicrob Agents Chemother. 2013;57(8):3746-51. https://doi.org/10.1128/AAC.00315-13.

30. Gutierrez-Valencia A, Torres-Cornejo A, BenMarzouk-Hidalgo OJ, et al. Darunavir minimum plasma concentration and ritonavir-boosted darunavir monotherapy outcome in HIV-infected patients. Antiviral therapy. 2014;19(5):443-7. https://doi.org/10.3851/IMP2722.

31. Lotsch J, Harder S, Sturmer M, et al. Association of saquinavir plasma concentrations with side effects but not with antiretroviral outcome in patients infected with protease inhibitor-susceptible human immunodeficiency virus type 1. Antimicrob Agents Chemother. 2007;51(9):3264-72. https://doi.org/10.1128/AAC.00036-07.

32. Smith $D E$, Jeganathan $S$, Ray J. Atazanavir plasma concentrations vary significantly between patients and correlate with increased serum bilirubin concentrations. HIV Clin Trials. 2006;7(1):34-8. https://doi. org/10.1310/0KXO-H9VH-99EE-5DOL.

33. Musarrat F, Chouljenko V, Dahal A, et al. The anti-HIV drug nelfinavir mesylate (Viracept) is a potent inhibitor of cell fusion caused by the SARS-CoV-2 spike (S) glycoprotein warranting further evaluation as an antiviral against COVID-19 infections. J Med Virol. 2020. https://doi. org/10.1002/jmv.25985.

\section{Publisher's Note}

Springer Nature remains neutral with regard to jurisdictional claims in published maps and institutional affiliations.

Ready to submit your research? Choose BMC and benefit from:

- fast, convenient online submission

- thorough peer review by experienced researchers in your field

- rapid publication on acceptance

- support for research data, including large and complex data types

- gold Open Access which fosters wider collaboration and increased citations

- maximum visibility for your research: over $100 \mathrm{M}$ website views per year

At BMC, research is always in progress.

Learn more biomedcentral.com/submissions 